\title{
The effects of hand soap making practice with addition of pineapple skin extract (Ananas comosus L. Merr) on learning interests in colloidal materials in senior high school
}

\author{
Seriana Zamilii ${ }^{1}{ }^{*}$, Lisa Ariyanti Pohan $^{1}$ and Uswatun Hasanah ${ }^{1}$ \\ 'Chemistry Education Study Program, FKIP, Universitas Islam Sumatera Utara, Medan, Indonesia \\ ${ }^{*}$ Corresponding author: (SZ), serianazamili44@gmail.com
}

DOI: 10.24114/jpkim.vlli3.15798

Received: 24 October 2019; Accepted: 30 November 2019

Abstract:

Learning by practicum method is a way of delivering learning material by providing opportunities to the students to practicein order to make the students engage in planned and active learning experiences so that students' interest grows on chemistry subject. The population in this study were the students of XI class at YAPSI Senior High School in Medan. The sampling technique is done by using the Quota sampling technique. The instruments were the student's interests in questionnaire and student activeness observation sheet. The requirements test is in the form of normality test and homogeneity test with the value of $\mathrm{L}_{\text {count }}=0.663$ initial interests data and $\mathrm{L}_{\text {count }}=0.172$ final interests data which means the data is normally distributed. In the homogeneity test $F_{\text {count }}=0.233$ initial interests data and $F_{\text {count }}=0.449$ final interests data with homogeneous results. The data analysis technique was done by using the hypothesis $\mathrm{t}$ test and $\mathrm{N}$-gain test. The results showed that the hand soap making practice with the addition of pineapple extract (Ananas comosus $L$.. Merr) had an influence on students' learning interest with $\mathrm{N}$-gain of 7.6 in experimental class data and $\mathrm{N}$-gain of 5.4 in control class data and from the $t$ hypothesis test obtained $T_{\text {count }}>T_{\text {table }}$ which $T_{\text {count }}=6.90$ and $T_{\text {table }}$ at level 0.05 is 2.01 so $H_{o}$ is accepted, which means that there was an influence of the handsoap making practice with the addition of pineapple skin extract (Ananas comosus $L$. Merr) on student interests in learning.

Keywords: Colloid; hand soap making practice; interests

\section{Introduction}

Chemistry is a branch of natural science that we often encounter in daily life. Lots of students find it difficult to study chemistry because chemistry is generally in the form of abstract concepts. According to Rachmawati (2014) abstract concepts are concepts that are difficult to understand in studying chemistry. One of chemical materials in the form of colloidal concepts matter. The concept of colloid is one of the theoretical material whose are abstract. In these materials students are required to memorize the concepts.

According to Lukman (2014) colloidal material is quite a lot of theoretical material and does not contain mathematical elements so that students learn the material by memorizing existing theories so that colloidal system materials seem boring and monotonous. According to Mariana (2016) colloidal material is material with characteristics consisting of concepts and understandings that are quite complex, for example in the steps of making colloids, their nature and types. Based from some opinions of these researchers it can be concluded that students' 
interest in learning chemistry especially in colloidal material is very lacking due to the nature of colloidal material in the form of concepts and understanding and requires students to memorize these concepts. It is recommended that the learning on colloidal material is related to something in daily life.

Based on the results of observations and interviews with chemistry teachers at YAPSI Senior High School Medan, where the teacher has been teaching with the lecture method all of this time without being accompanied by an activity or direct practice to make a product that can be utilized especially on colloidal material causing the lack of the students interest in learning chemistry. This is evidenced by the condition of students who are less active during the teaching and learning process, not doing the assignments given by the teacher and there are still many students whose learning outcomes have not yet reached the KKM, with data on the value of learning outcomes on the subject matter of colloid material obtained an average class was 72, with completeness results in 1 class of 14 students out of 25 students. Based on the Minimum Completion Criteria (KKM) in chemistry subjects was 75 , the learning outcomes in this class were still less than $75 \%$. One of the efforts to increase the student's interest in learning chemistry on colloidal material is by conducting learning in the form of experiments or practicum. As stated by Dinastyawan (2016) that learning accompanied by practicum has a positive effect on student interest in learning that can be seen from an increase in average student learning outcomes that achieve mastery learning from 13 students to 38 students.

In this study the experiment conducted by the practice of making products of economic value, namely hand soap making practice using pineapple extract (Ananas comosus L. Merr) whose processed by colloidal system in which students understand the concepts during the practice.ln this learning activity with these experimental methods, students can understand the concepts through the process of experiencing and make learners more active in accordance with the 2017 curriculum which demands that teacher-centered learning patterns be transformed into student-centered learning patterns in order to make the learning objectives can be achieved well (Pemendikbud, 2017).

Based on the background, several problems can be identified, which are: (1) The lack of students' interest in learning chemistry on colloidal material, (2) In the learning process on colloidal material the teacher solely relies on conventional learning methods or lecture methods, (3) In the learning process the teacher does not use the practicum method/ the teacher does not explain the application of colloids in everyday life. For this reason, it is necessary to limit the problem which was focused on efforts to increase the students' interest in learning chemistry with colloidal material in everyday life, in the manufacture of hand soap using pineapple skin extract (Ananas comosus L. Merr) in YAPSI Senior High School Medan. The formulation of the problem in this study are ( 1 ) how was the practice of hand soap making with the addition of pineapple skin extract (Ananas comosus L. Merr) applied to colloidal material? (2) How was the participation of students in the practice of making hand soap with the addition of pineapple skin extract (Ananas comosus L. Merr)? (3) Did the effect of practicum in hand soap making with the addition of pineapple skin extract (Ananas comosus L. Merr) can increases the student interests in learning? While the aim was ( 1 ) To find out the process of hand soap making with the addition of pineapple skin extract (Ananas comosus L. Merr) can be applied to the colloidal system, (2) To determine the students' participation in hand soap making practice with the addition of pineapple skin extract (Ananas comosus L. Merr) which was applied to colloidal material, (3) To find out how much the increases in students' interest in learning chemistry in colloidal material through the practice of hand soap making with the addition of pineapple skin extract (Ananas comosus L. Merr). 


\section{Methods}

This research was an experimental research conducted at YAPSI Senior High School Medan which is located at Jalan Sehati No.50 Tegal Rejo Medan Perjuangan. This research lasted for 2 weeks starting from 9 April 2019 to 15 April 2019. The population in this study were all students of XI class IPA 11 semester at YAPSI Senior High School Medan consisting of 2 classes namely IPA-1 and IPA-2. Sampling was done by Quota Sampling where the samples were determined directly by researchers with chemistry teachers at YAPSI Medan High School with IPA-1 as the experimental class and IPA-2 class as the control class.

This research was an experimental research, which was a research in the form of the practice of hand soap making with the addition of pineapple skin extract (Ananas comosus L.. Merr) which was applied to colloidal material with the aim to find out its effect on students' learning interest. This research involved two classes as samples with different treatments. To find out the interest in learning chemistry students would be given an initial interest questionnaire (before treatment) and a final interest questionnaire (after treatment is given) that analyzed with qualitative descriptive analysis (Table 1).

Table 1

The percntage of final interest of students

\begin{tabular}{lll}
\hline No & Indicators & $\%$ Interests \\
\hline 1 & Attention & $89.58 \%$ \\
2 & Participation & $85.42 \%$ \\
3 & Feelings of joy & $94.44 \%$ \\
\hline
\end{tabular}

\section{Results}

\section{Student participation in learning with practicum}

From the results of student observation questionnaire during the learning process between IPA 1 class as the experimental class given treatment in the form of experimental learning by making hand soap using pineapple skin extract (Ananas comosus L.. Merr) and IPA 2 class as the control class with conventional learning models obtained from observational data from 10 statements, where the qualitative statements are converted into quantitative form in order to obtain the results of observations of student activation in the form of numbers.

Table 2 shows that the activeness of students during the learning process based on the observation sheet of learning interest, namely the indicators of Attention in the KBM was $89.58 \%$, Participation in the KBM was $85.42 \%$ and Feelings of Joy for the KBM was $94.44 \%$. It shows that the average percentage of the student activity was $85.81 \%$ which categorized as very high.

Table 2

The Percentage of students activity based on the observation sheet (control class)

\begin{tabular}{lll}
\hline No & Indicators & \% lnterests \\
\hline 1 & Attention & $47.75 \%$ \\
2 & Participation & $47.92 \%$ \\
3 & Feelings of joy & $31.25 \%$ \\
\hline
\end{tabular}

Table 2 shows that the activeness of student learning based on the observation sheet of learning interest, namely the indicators of Attention in the KBM was $47.75 \%$, Participation in the KBM was $47.92 \%$ and Feelings of Joy KBM was $31.25 \%$. From these data we can see that the average percentage of student activity in the control class was $42.30 \%$, in the medium category. 


\section{The effects of practicum on learning interest}

From the results of the initial interest questionnaire and the final interest questionnaire in the two classes which was XI IPA 1 as the experimental class and XI IPA 2 as the control class, it had obtained from the instrument of interest statement as many as 25 statements, where the questionnaire statement in the form of qualitative is converted into quantitative form so that it gets the results of interest in the form of numbers. The initial interest questionnaire was given before treatment, then converted into a percentage of interest based on a Likert scale. Whereas, the final interest questionnaire was given after the learning process with the practice of hand soap making using pineapple skin extract (Ananas comosus $L$. Merr) in XI IPA 1 as the experimental class and after learning the conventional method in XI IPA 2 as the control class. The following is a chart of questionnaire data of control class interests, initial experimental class and final experimental class (Fig 1).

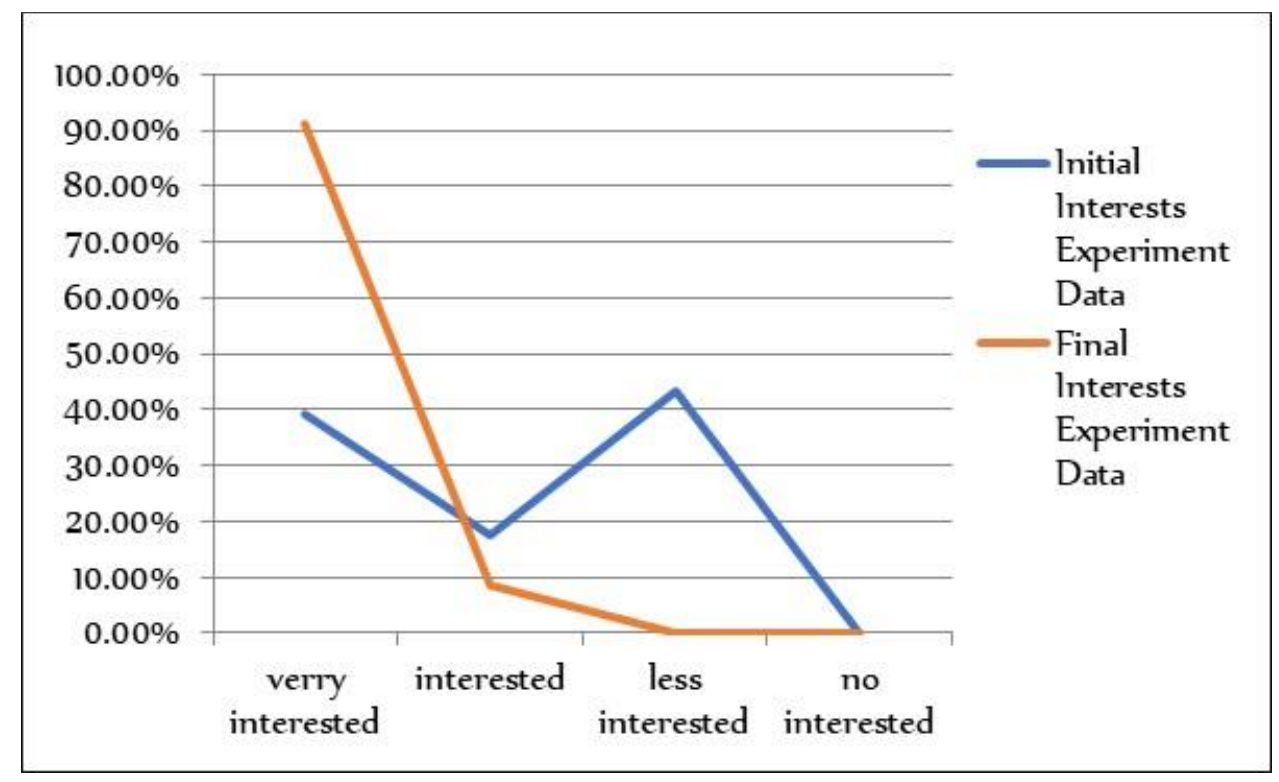

Fig 1. Interests in Learning (experimental class)

Based on Fig 1 it can be seen that the percentage of students' learning interest in the experimental class increased from the initial interest to final interest. With practicum methods, students' learning interest has a big impact on increasing the students' learning interest (Table 3). For more details let's take a look on following chart (Fig 2).

Table 3

Interests data (experiment class)

\begin{tabular}{lcc}
\hline \multicolumn{1}{c}{ Categories } & Initial & Final \\
\hline Very Interested & $39.13 \%$ & $91.30 \%$ \\
lnterested & $17.39 \%$ & $8.70 \%$ \\
Less Interested & $43.47 \%$ & $0 \%$ \\
Not Interested & $0 \%$ & $0 \%$ \\
\hline
\end{tabular}




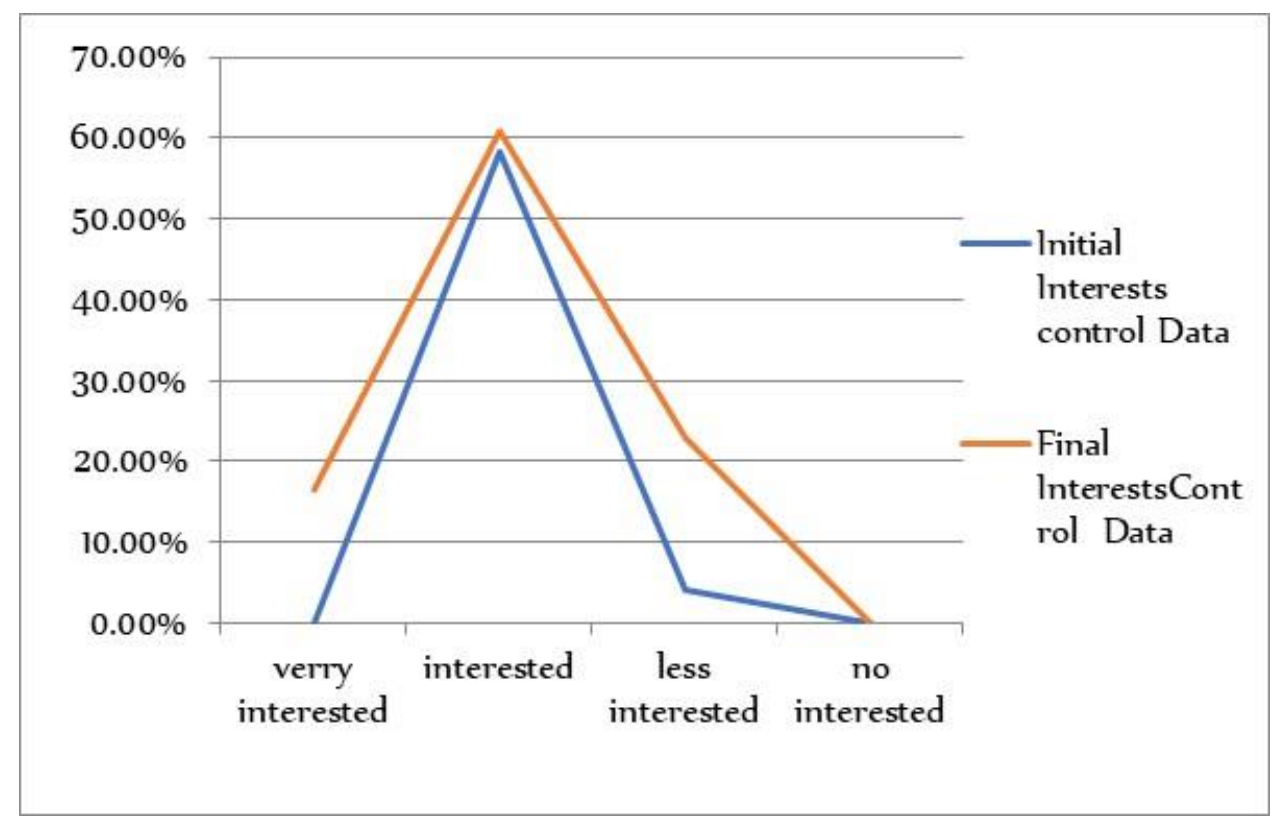

Fig 2. Learning interests (control class)

Based on Fig 2 it can be seen that the students' learning interest in the control class based on the percentage of initial interest and final interest has a slightly difference results. For more details let's take a look at the following Table 4.

\section{Table 4}

Interests data (control class)

\begin{tabular}{lcc}
\hline \multicolumn{1}{c}{ Categories } & Initial & Final \\
\hline Very Interested & $0 \%$ & $16.6 \%$ \\
Interested & $58.33 \%$ & $60.83 \%$ \\
Less Interested & $4.16 \%$ & $23 \%$ \\
Not Interested & $0 \%$ & $0 \%$ \\
\hline
\end{tabular}

\section{Discussion}

The discussion in this study includes the effect of the hand soap making practice using pineapple skin extract (Ananas comosus L. Merr) on students' learning interest. Pineapple skin extract (Ananas comosus L. Merr) contains natural compounds namely tannins which function to regenerate the skin, saponin which functions to add foam to soap and flavonoids that function as an anti-bacterial which is used as an additional material in the manufacture of hand soap (Manaroinsong, 2015; Situmeang et al. 2019; Salasa et al. 2019; Daely et al. 2019; Yusliana et al. 2019).

Soap is an example of a colloidal system that acts as an emulgator in emulsions between water and oil or between water and dirt on the palm of the hand with a solid dispersed phase and a liquid dispersing medium called a liquid sol. Colloids with liquid dispersion medium can be divided into lyophilic colloids (likes liquid) and liofob colloids (hates liquid). If the medium is water dispersion, it is divided into hydrophilic colloids (likes water) and hydrophobic colloids (hates water). Soap is hydrophobic colloid, because of these properties, dirt can be separated from the palm of the hand mixed with water. 
Based on the data analysis steps that have been carried out on the results of the study, it can be obtained a clear picture of the problems contained in this study, that interests in learning is one of the main factors in achieving success in learning. Referring to the understanding of interest in learning according to Purwanto (2014)said that interest is an important foundation for someone to do activities well, that impulses someone to act. Therefore, it is very necessary to attract the interest of the students, one of the ways is by doing learning in the form of practical work that can lead to student activity and the desire of the students to learn (Silaban, 2017; Lukman et al. 2019).

As was done in this study, learning with practical methods such as the hand soap making practice using pineapple skin extract (Ananas comosus L. Merr), can provide a significant influence on student interests in learning. In terms of the data analysis of student activeness between the experimental class given treatment in the form of practicum and control class with the lecture method there was a significant difference in the percentage of student activeness ie for the experimental class was $89.81 \%$ while the control class was $42.30 \%$. Based on the analysis of interests obtained the average value of early learning interests in the experimental class and control class respectively 4.82 and 1.92, while the average value of the final interests carried out in the experimental class was 85.65 and the control class was 65.58. Interests incresing in the experimental class included in the medium category with an average $\mathrm{N}$-Gain value of 0.31 . While the learning interests increasing in the control class is included in the low category with an average $\mathrm{N}$-Gain value of 0.23 . Based on the results of the analysis of these data it can be stated that learning with practicum affects student learning interest even though the level of improvement is not too high. This was due to the practicum modules which were less applicable to the learning material as well as limited research time. From the interviews with several students in the experimental class, the researcher concluded that learning with practicum methods made the students more active and more interested in learning because when the students learning by doing the practicum they got new informations that could lead them to enjoy the learning activity. While based on the results of interviews with several students in the control class the researcher concluded that learning with the lecture method makes the students feel quickly boring so the students became not interested in learning activity.

\section{Conclusion}

Based on the results of research and data analysis it can be concluded that: (1) Learning the colloidal material through the hand soap making practice with the addition of pineapple skin extract (Ananas comosus L.. Merr) makes students not boring in learning activity because they get new knowledges through the practicum; (2) Student participation in the learning activity through the hand soap making practice with the addition of pineapple skin extract (Ananas comosus $\mathrm{L}$. Merr) in the experimental class was very high $(89.81 \%)$ while in the control class was in the low category (42.30\%); and (3) Learning activity through the hand soap making practice with the addition of pineapple skin extract (Ananas comosus L. Merr) has an influence on increasing student interests in learning with an $\mathrm{N}$-gain value of 0.31 (experimental class) and 0.23 (control class).

\section{Acknowledgments}

The researcher would like to thank: (1) Balai Laboratorium Kesehatan in Medan which has helped give permission to researcher to use centrifuges to centrifuged pineapple skin extracts (Ananas comosus L.. Merr) which are used as additives in the manufacture of hand soap; and (2) Medan YAPSI School which has given permission to researcher to conduct research in class XI IPA-1 and class XI IPA-2 Medan YAPSI Senior High School. 


\section{References}

Daely, P. J., Sarwendah, S., Laia, H. C., \& Damardi, S. (2019). Uji daya hambat anti bakteri air perasan daging buah nanas (Ananas Comosus (L) Merr Var. Queen) terhadap Bakteri Eschericia coli. Jurnal Ilmiah Universitas Batanghari Jambi, 19(2), 239-241, doi: 10.33087/jiubj.v19i2.610

Suyitno, E. D. (2016). Pengaruh pembelajaran e-learning dan praktikum otomotif teradap minat belajar siswa kelas xi program studi TKR di SMK Nawa Bhakti kebumen tahun ajaran 2015/2016. Auto Tech: Jurnal Pendidikan Teknik Otomotif Universitas Muhammadiyah Purworejo, 8(1), $108-112$.

Lukmana. 2014. Analisis keterampilan proses sains siswa SMA pada sub pokok bahasan sifat-sifat koloid dalam kehidupan melalui pembelajran STM. FKIP. Universitas Jember.

Lukman, 1., Damanik, M., Silaban, S., \& Kembaren, A. (2019). Development of problem based learning innovative student worksheets in learning the concept of chemistry for senior high school students. Journal of Transformative Education and Educational Leadership, 1(1), 23-28.

Manalu, E., Silaban, S., Silaban, R., \& Hutabarat, W. (2016). The development of chemical practice guidebook colloid system-based integrated contextual character values. Jurnal Pendidikan Kimia, 8(2), 87-89.

Manaroinsong, A. (2015). Uji daya hambat ekstrak kulit nanas (Ananas comosus $\mathrm{L}$ ) terhadap bakteri Staphylococcus aureus secara in vitro. Pharmacon, 4(4), 27-33

Penyusun, T. (2013). Kerangka dasar dan struktur kurikulum sekolah menengah atas/madrasah aliyah. Jakarta: Kemendikbud.

Purba, D. N., Damanik, M., Silaban, S., \& Simatupang, L. (2018). The difference of student's activities and learning outcome with problem based learning using macromedia flash and handout. Jurnal Pendidikan Kimia, 10, 403-408, doi: 10.24114/jpkim.v10i3.12704

Purwanto. (2014). Evaluasi hasil belajar. Yogyakarta: Pustaka Pelajar.

Rachmawati, L. (2014). Pengembangan dan penerapan instrumen diagnostik two-tier dalam mengidentifikasi miskonsepsi siswa tentang atom dan molekul. Edusentris, 1(2), 146-155.

Salasa, A. M. (2019). Aktivitas ekstrak kulit buah nanas (Ananas comosus L.) terhadap pertumbuhan Pseudomonas aeruginosa. Media Farmasi, 13(2), 1-5.

Situmeang, B., lbrahim, A. M., Bialangi, N., Musa, W. J., \& Silaban, S. (2019). Antibacterial activity and phytochemical screening of Kesambi (Sapindaceae) against Eschericia coli and Staphylococcus aureus. Jurnal Pendidikan Kimia, 11, 14-17, doi: 10.24114/jpkim.v1li1.13078

Yusliana, Y. (2019). Uji daya hambat antibakteri air perasan daging buah nanas (Ananas comosus ( $\mathrm{L}$ ) Merr Var. Queen) terhadap bakteri Salmonella typhi. Scientia Journal, 8(1), 1-9, doi: 10.35141/scj.v8il.388 